\title{
Miranda
}

Revue pluridisciplinaire du monde anglophone /

Multidisciplinary peer-reviewed journal on the English-

speaking world

$21 \mid 2020$

Modernism and the Obscene

\section{Ezra Pound's Representations of Sexual Intercourse and the Female Genitalia in The Cantos}

\section{Emilie Georges}

\section{OpenEdition}

Journals

\section{Electronic version}

URL: http://journals.openedition.org/miranda/27937

DOI: 10.4000/miranda.27937

ISSN: 2108-6559

Publisher

Université Toulouse - Jean Jaurès

\section{Electronic reference}

Emilie Georges, "Ezra Pound's Representations of Sexual Intercourse and the Female Genitalia in The Cantos", Miranda [Online], 21 | 2020, Online since 09 October 2020, connection on 16 February 2021 URL: http://journals.openedition.org/miranda/27937 ; DOI: https://doi.org/10.4000/miranda.27937

This text was automatically generated on 16 February 2021.

\section{cc) (i) () $\Theta$}

Miranda is licensed under a Creative Commons Attribution-NonCommercial-NoDerivatives 4.0 International License. 


\title{
Ezra Pound's Representations of Sexual Intercourse and the Female Genitalia in The Cantos
}

\author{
Emilie Georges
}

1 Ezra Pound, author of the eight-hundred-page-long Cantos, is not known as an erotic poet, despite being self-admittedly a great admirer of both Ovid and Catullus (see e.g. Pound, 1961, 33, 47, 58, 104)-and John Gery, in his analysis of "The Thought of What America," emphasises how obvious the erotic and even obscene qualities of some classical texts were to people who, like Pound, knew them well (Gery 189). There are, however, passages that deal with sexuality in The Cantos, most notably in Cantos xxIX, XXXIX, and XLVII, and Pound's ways of dealing with the theme has been commented upon by such critics as Leon Surette (A Light for Eleusis 1979), Peter Makin (Provence and Pound 1978), and Robert Casillo (The Genealogy of Demons 1988). They generally emphasise the sacred dimension that sexuality takes on in Pound's poetry, apparently following the medieval Provençal conception of sexuality, and highlight Pound's masculinist heterosexual vision-with its idealisation of woman and its strong focus on the role of the phallus. What has been less commented on is the ways in which Pound represents the female genitalia. We know that he was not afraid of being crude and some of his early poems-in Blast and Lustra especially-were deemed obscene at the time (Stock 162-163, 194-195). In The Cantos he still called a phallus a phallus but in his representations of the female genitalia he resorted to a greater variety of poetic devices-the effects of which range from idealisation to disgust, reflecting the diversity noted in society at large by Braun and Wilkinson ("Sociocultural Representations of the Vagina," 2001). Analysing these diverse representations will enable us to better apprehend Pound's conception of women and sexuality and how it relates to his vision of economics and politics (in the broadest sense of the word). 


\section{Mortal women and the eternal feminine in Ezra Pound's life and writings}

2 Before embarking on this exploration of the representations of the female genitalia in Ezra Pound's Cantos it may be useful to offer a few comments on the poet's relationships with women throughout his life. Taking this biographical factor into consideration is all the more interesting as he came of age during the first wave of feminism (which spanned the second half of the nineteenth century and the first two decades of the twentieth century) and died in 1972 just as the second wave was taking off. In certain respects he was very much a man fully ensconced in his patriarchal ways: he had a reputation as something of a ladies' man, having been dismissed from a teaching position because a woman had been found in his rooms (Stock 42). He also had a wife he never left, Dorothy Shakespear, as well as a lifelong mistress, the violinist Olga Rudge. Although this view of him as a successful lover is sometimes qualified (Nicholls 72), the facts tell us that his romantic relationships worked very much to his advantage.

3 As for his professional relationships with women, he seemed to offer advice to them with the same alacrity that he did men, his most famous protégées being Iris Barry and Marianne Moore (Stock 193, 435), and was not loath to accept financial support from women either, as shown by his relationships with Margaret Cravens and Harriet Monroe, the founder of Poetry (Stock 121; Dennis 1999, 268). Helen Dennis argues that Pound is ambivalent in his relationships with women and specifically notes the "contradictions between his work as promulgator, collaborator and colleague to literary women such as H.D., Gertrude Stein, Marianne Moore, and his sense of the ideal feminine" (Dennis 1999, 265).

4 Nowhere is this more evident than in his relationship with the poet H.D.: she recounts in End to Torment the well-known event of the creation of Imagism when Pound deemed her an Imagist (H.D. 18) which evinces his admiration of her as a poet and his support of her endeavours (although one may well argue that, by naming the movement, he retained a paternalist form of control over her work), but she also recalls instances when his patriarchal mindset is more obvious, such as his deeply unsettling visit to her hospital room when he regretted that the child she was about to give birth to was not his (H.D. 8, 30, 33, 41). The importance of the question of paternity in the patriarchal system has been studied by second-wave feminists such as Kate Millett (112) and while Pound's remark to his former lover H.D. may seem more wistful than bitter, there is undoubtedly a darker side to it for the modern reader who knows that proof of paternity authorises patriarchal control over the mother. His nickname for her, "Dryad" (H.D. 12, 17, 18), evokes the nymphs of Greek mythology and Dennis is quick to point out that by "characteriz[ing] her as a tree nymph" he did not "address her as an equal" but rather "cast her in romantic versions of the archetypal feminine" (Dennis 1999, 273).

5 This notion of the archetypal feminine has been identified by feminist thinkers such as Germaine Greer as the embodiment of beauty (63), celebrated by male artists and poets (64-65) and presented to women as an unattainable ideal. Greer (67) emphasises this idealised woman's complete lack of agency and Dennis's analysis follows the same line: she sees in those of Pound's poems which are concerned with H.D. a "compulsion to write this fellow Imagist poet back into the myth of Daphne, back into the role of inspiring muse" (Dennis 1999, 274). More generally, Pound celebrated goddesses 
throughout his Cantos and the importance of Aphrodite, the Greek goddess of love and beauty, in the very structure of his poem has been identified by various scholars (see e.g. Casillo 1985, 145; Bacigalupo 30-31). The representation of women as types extends to his closest relationships: Helen Dennis tells us that he identified his wife with the type of the Victorian angel and Olga Rudge with the goddess of love (Dennis 2010, 408). If one remembers that Pound had been much influenced by Victorian literature (Paul 20-21), a main aspect of which was the idealisation of women and love (Millett 127-128), the poet's aesthetic seems fully consistent with the ideas of the era during which he came of age and not at all exemplary of any avant-garde thinking on gender-related questions (Dennis 1999, 265).

6 One final aspect to be explored here is the question of sexual violence which, as Casillo $(1988,228)$ noted, is absent to the point of having been erased in certain passages which Pound took from classical texts, such as the sexual relations between Ulysses and Circe in Book x of Homer's Odyssey. This may seem paradoxical, but it is consistent with the idealisation of love which Pound scholars have often underlined in his work (Sieburth 164; Casillo 1985, 140) and with Millett's contention that the use of force has been made invisible by the success of patriarchy in garnering general assent, even from women (Millett 43). Simply put, Pound did not see the need for violence in sexual matters. What makes this more disturbing is the fact that he also refused to acknowledge violence in political matters, more specifically in the case of Italian Fascism (Pound 1935, 51). We thus begin to see how politics and sexuality may be entwined in Pound's aesthetic. At this point, one might expect there to be no explicit references to the female genitalia in Pound's Cantos, since he favoured an idealised vision of love and sexuality, but it is not the least of Pound's contradictions that his poem does contain some such allusions.

\section{The messy female genitalia: enemy to the poet?}

7 Commenting on Canto xxxIx William Cookson (55) remarks that "[s]ex, the mysterious life-force of the universe, has a sacred dimension in The Cantos which is at a far remove from the trivialization and commercialization of sexuality that has been steadily increasing since the poem was written." Although this sounds very much like the conservative thinking of a man who belongs to an older generation, it also indirectly points to the relation that Jean-Michel Rabaté identifies between Pound's approach to sexuality and his economics. Rabaté argues that for Pound "magic, money and sexuality ultimately lead to the same affirmation of fecundity" and so we cannot understand the poet's approach to sexuality without considering his economics and vice-versa (Rabaté 216). While Cookson speaks of a "commercialization of sexuality" that is absent from Pound's Cantos, Rabaté perceives in the poem the poet's desire for fluidity, for good circulation (218-219) that would effectively link economy-or the circulation of money-with sexuality-or a circulation of genital fluids through intercourse. As Rabaté indicates, money that does not circulate "congeals" and we might imagine, although Pound never explicitly said as much, that the same would symbolically happen to the soft flesh of the vulva since Rabaté tells us

The enemy is for Pound the soft mass, the bloated flesh, and the striking feature is that phallic assertion needs the 'cutting' quality of thought, which dissociates, dissects the 'clots' which become clogs. (Rabaté 219) 

image of the soft-flesh-as-enemy applies to such figures as Pope Pius the Second ("Papa Pio Secundo") who is a "swollen, swelling s o b" (Pound 1996, x, 44), the same cannot be said of female genitalia, which are never considered dangerous to man in The Cantos. Robert Casillo remarked on the paradox of that non-threatening softness, reflecting that one of the elements of Italian Fascism which attracted Pound was "its masculine cult of 'hardness"' (Casillo 1988, 91). Similarly, Richard Sieburth argued that "the Other or the excess that needs to be vigorously eliminated from contemporary art" is designated by Pound's preference for "phallic metaphors" "as somehow feminine or excremental-soft, slushy, slithery, ambiguous, indefinite, internal" (Sieburth 149). Where economy and sexuality are linked is not so much in that image of the soft-fleshas-enemy as in the need for circulation (Sieburth 152-153; Casillo 1985, 127) and for an ordering principle which is always symbolically phallic for Pound: Rabaté speaks, after Pound, of "the 'cutting' quality of thought" (Pound, "Cavalcanti" 1968, 154) and Pound himself explicitly links coitus and ideation, and the phallus and innovative thought in the postscript to his translation of Remy de Gourmont's Natural Philosophy of Love ( $\mathrm{La}$ Physique de l'amour):

There are traces of it in the symbolism of phallic religions, man really the phallus or spermatozoide [sic] charging, head-on, the female chaos. Integration of the male in the male [sic] organ. Even oneself has felt it, driving any new idea into the great passive vulva of London, a sensation analogous to the male feeling in copulation. (Gourmont, Pound trans. 1922, 207)

In these now famous sentences Pound assigns a receptive role to the vulva or "female chaos". It seems here that the female organ is undifferentiated matter, following Gourmont's assertion that in nature the female is primitive and differentiation is a male prerogative (Gourmont, Pound trans. 1922, 31) and that this matter can only be shaped by heterosexual intercourse, by phallic penetration. Feminist thinkers remark that the primordiality of the female may be true from a scientific point of view (Greer 30; Millett 30), but they emphasise the unimportance of the differentiation which then takes place. Construing this primordiality as a primitiveness to be shaped by a man's action is a purely patriarchal interpretation which only serves to reinforce male power. As previously mentioned, Helen Dennis has pointed out the contradiction between Pound's traditional, heteronormative ideas and his support of female modernist artists whom he knew; she analyses the above-quoted passage in the following manner:

Pound's theory seems to want to tease out a connection between the physiology of heterosexual desire, the image-making faculty and the visionary experience of the mystic or initiate. It is a theory which confers glamour on women and elevates them to the status of mantra or divine muse, but which sits uneasily with a full consideration of the political rights of individual women to autonomy and equality. (Dennis 1999, 276)

Like other Poundian scholars (Surette 97; Makin 1978, 250), she links Pound's representations of sexuality with mysticism, but Dennis is not blind to the poet's faults and biases, writing elsewhere:

Woman is seen as biologically inferior to man, something of a biological mess at times. The masculinist theory of genius which he propounds in his translator's postscript informs Canto xxIx, which is problematic since its tone is unstable, possibly ironic. (Dennis 2010, 406-407) 
11 Dennis finds it difficult to analyse this Canto because its unstable tone leaves too much uncertainty as to Pound's meaning(s). Her attempts at interpretation remain at a distance from the text as she focuses on Pound's ideas rather than on his language. Consider this extract from Canto XXIX:

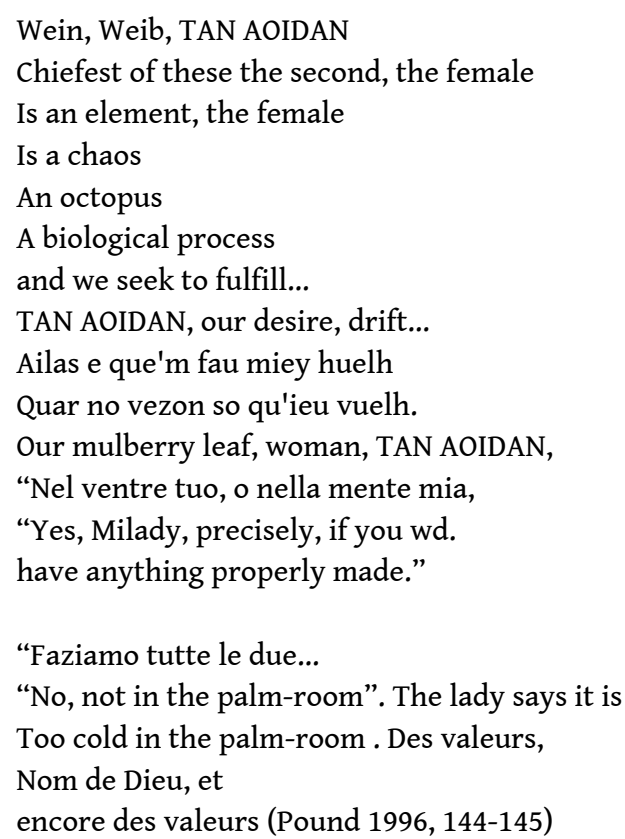

No image here is directly related to the female genitalia by the poet, but because of the postscript to The Natural Philosophy of Love we easily associate "the female/Is a chaos" with "the female chaos" that the phallus "charg [es], head-on," and therefore it seems equally easy to associate the other images, the soft flesh of "an octopus" and the "biological process," with that specific part of the female body. What we find is thus a synecdochical picture of woman where she is defined by her reproductive system, as a female rather than a woman. This tendency to refer to women synecdochically has been noticed by feminist thinkers such as simone de Beauvoir who spoke of how certain people reduce woman to "a matrix, an ovary" ("une matrice, un ovaire" Beauvoir 37) and Germaine Greer who explained that a woman herself, and not only her genitals, is sometimes referred to as "a gash" (Greer 297). It does not change much that Pound afterwards refers to the female character as "woman" (which does not seem to be a word of address but rather an apposition to "our mulberry leaf") and "milady" in the dialogue and then as "the lady" to introduce another piece of dialogue: these last two terms have an ironic ring (Greer 295) and while we move away from biological images to a social image of woman, sex, the biological function to which women are so often reduced (Millett 119) is still very much at the heart of the matter. The picture these terms-"chaos," "octopus," "biological process"-convey to us is one that is, like the tone of the Canto according to Dennis, unstable, messy, and rather unappealing.

This messiness, however, is not woman's alone. Pound also gives us a mixture of five different languages-not including English-in the course of about twenty short lines. This results in competing atmospheres and contributes to the tonal instability of the Canto: while the use of a cut-off German phrase ("Wein, Weib [und Gesang]"1) evokes a festive, rowdy spirit, the Greek takes us back to ancient rituals and the Provençal to the amorous atmosphere of troubadour poetry. The Italian is twofold: medieval with the adaptation of Dantescan lines (Terrell 117) and contemporary with the spoken 
sentence: "faziamo tutte le due". The orality of the latter sentence is marked by the spelling: faziamo instead of facciamo, which could indicate a variation in pronunciation; the meaning of the sentence is also unstable because it can be understood as either "let's do it together" (Terrell 117), if we surmise that Pound made a mistake in transcribing a phrase he had heard (tutti e due or tutt'e due meaning "together"), or "let's do both" (Edwards et al. 67). Either way, we feel the context to be that of a sexual encounter in which a man tries to have his way with a woman who resists him: the contemporary Italian outlines his virile, amorous enterprise while the spoken French ("Des valeurs,/Nom de Dieu, et/encore des valeurs") sounds like a jocular comment from an amused passer-by or a Flaubertian narrator. Pound thus adopts several personae in the course of these few lines to give us a multiplicity of cultural perspectives, all of which inform his approach to sexuality: it is all at once masculine, jocular, festive, poetic, and mystic. It is also sexist in its synecdochical, messy representation of woman and her genitalia.

In Pound's use of the words "chaos," "octopus," and "biological process" we find an unappealing picture of the female body, but not one which seems to cause real disgust in the speaker. This changes in Canto Xxxv where Pound's anti-Semitism surfaces in an image that is at once sexist and racist, reducing both women and Jewish people to an association with the-apparently disgusting-lower body:

this is Mitteleuropa

and Tsievitz

has explained to me the warmth of affections,

the intramural, the almost intravaginal warmth of

hebrew affections, in the family, and nearly everything else.... (Pound, 1996,

172-173)

Because of Pound's known anti-Semitism, we know that that image of "almost intravaginal warmth" cannot be understood as reassuring (as the warmth and cosiness of a home can be) to the speaker. His anti-Semitism as well as his Anglophobia would only increase as the Italian Fascist regime grew harsher and more intolerant towards dissidents and people whom it considered inferior in the years leading up to and during the Second World War. Interestingly, each of these two themes-anti-Semitism and Anglophobia-is associated at least once in the poet's writings with a vulvar image. In The Natural Philosophy of Love he had written of "the great vulva of London" and in a letter to William Carlos Williams written in the same year he would be even more aggressive in his phrasing, as Helen Dennis tells us:

The First World War had decimated the young male population leaving "a greater proportion of females above that of males (which) makes it THE land for the male with phallus erectus. London THE cunt of the world." (Dennis, 1999, 276)

She adds that his use of a Latin word for the male organ and of the slang word "cunt" for the female genitalia is "significant". According to her, "Pound is not talking biology so much as culturally positioning himself within the dominant order which is phallogocentric." (Dennis, 1999, 276-7). As accurate as that analysis may be, it does not tell us much about the reasons why Pound chose the very specific word "cunt," which is often regarded as one of the most vulgar in the English language and among the most offensive insults which can be thrown at another person. As we shall see later, Pound did not abstain from using Latin words to denote the female genitalia in The Cantos. In this letter, however, he chose a word which has a very specific connotation: it is most probable that he deliberately chose this slangy female counterpart to the Latinate male 
phallus as an insult to London which, after the First World War, became for him not only a land of "females" but also a land of defenders of usury such as Winston Churchill (Pound, 1978, 285, 395) whom he would come to abhor: the pun on "cunt" is intended.

Pound also chose at times to use ellipses, rather than explicit words, as in "Il est tombé dans le/de sa femme" (Pound 1996, XxviI, 129), literally "he fell into the/of his wife". We can make a number of hypotheses regarding the word that this blank stands for: it could quite simply be a term, either common or vulgar, which denotes the vulva or it could be a word such as filet (net) or piège (trap) that has no explicitly sexual connotation but pertains to the traditional domain of sexist wife jokes. ${ }^{2}$ It could also be the more generic word trou (hole), as in the phrase "tomber dans le trou," which would imply that the man has been waylaid and is now stuck in a hole. This hypothesis can be related to another example of bodily humour, the common French joke " $t$ 'es tombé dans le trou ?" (have you fallen in?) which is said to someone who has stayed on the toilet for a long time.

Pound's knowledge of colloquial French has not been discussed as much as his knowledge of contemporary Italian, but it is quite possible that he knew enough to make such a joke. Dudley Fitts, who reviewed the typescript of The Pisan Cantos, thought Pound's French was actually better than his Italian (Ten Eyck 47) and later in The Cantos the poet also uses the phrase "maison close" (Pound 1996, C, 716), which Terrell merely translates as a "closed house" but which also means "brothel" (Terrell 648). It seems probable that it is not a mere coincidence that Pound chose this phrase because the more usual term for "closed" in French is fermé (e). More simply, the missing word could be a spoken word that Pound, a non-native speaker, did not catch, which fact he thought it would be amusing to include in his rendering of the sentence in his Cantoperhaps knowing that people would imagine something obscene. The study of his typescripts and of the first editions of the first thirty Cantos ${ }^{3}$ shows that Pound hesitated between "le" and "la," that is, between a masculine and a feminine noun. This could be because of an imprecise knowledge of French grammar on Pound's part or it could indicate that he changed his mind as to what word should be implied by the ellipsis. Whatever the case may be, that word does not appear anywhere and was apparently always meant to remain a mystery to the reader.

The line break after "le" highlights the fact that it is a broken sentence and emphasises the absence of the noun we expect while perhaps also conveying the idea of a fall into oblivion. Leaving a blank allows the reader to fill in what is missing and to imagine what they please. The common use of ellipses to elide obscenities easily suggests a sexual image to the reader's mind. It is very probable that Pound's humour surfaces here, as in other French passages in The Cantos (e.g. Canto xxIx), and that the French language is, in Pound's poetry, a cue that invites the reader to look for comedy.

\section{Between fecondità and luxuria: ambivalence towards sexual intercourse}

In spite of those subtle traces of humour, the tendency in Poundian criticism has often been to focus on the aestheticisation of intercourse in the form of the phallic line giving shape to the formless female matter (which, contrary to the phallic line, is "sensitivity without direction," Canto xxxv, 173) or on the mystic dimension of sexual 
intercourse that Pound perceived in troubadour poetry (e.g. Pound 1973, 70), but that focus on the sacred dimension of the sexual passages has also meant that commentators have rarely reflected on their explicitness. By way of example, let us consider this extract from Canto vI:

WHAT you have done, Odysseus,

We know what you have done...

And that Guillaume sold out his ground rents

(Seventh of Poitiers, Ninth of Aquitain).

"Tant las fotei com auzirets

"Cen e quatre vingt et veit vetz..."

The stone is alive in my hand, the crops

will be thick in my death-year... (Pound 1996, 21)

In that short passage, which constitutes the beginning of Canto VI, the elements which we will find in other Cantos concerned with sexuality-good stone and good crops, the figure of Odysseus, and lines from a Provençal troubadour song-are reunited: they are markers of a world that is, according to Pound, free from usury. The poetic cluster "death-year" is repeated in Canto XLVII ("doth thy death year/Bring swifter shoot?"), where the figure of Odysseus is present as well and which is also concerned with the sacred and ritualistic dimension of sexual intercourse. We can also note that the Provençal lines are very sexually explicit. Peter Makin translates the two lines but only remarks that they tell us of Guillaume d'Aquitaine's role as economic, cultural, sexual, and ritual fertiliser (Makin 1978, 75). We can construe their meaning as: "I fucked them, as you will hear, a hundred-and-eighty-eight times..." Tant, which is not really translatable here but literally means "so much," underlines the astonishing effect of the number found in the second line. This tale of sexual prowess, told in vulgar Provençal (foter being of the same register as "to fuck") is, to quote Cookson, "at a far remove from" our common, modern conception of the "sacred dimension" that one might find in sexuality.

In this particular instance it is difficult to see the restraint which Makin identifies as an important aspect of Pound's conception of the troubadours' approach to sexuality (Makin, 1978, 250) and Casillo tells us that Pound "never defines discursively the correct 'proportion' between restraint and sexual fulfilment," preferring instead to "symbolize it mythically, as in the combination of Venus Genetrix and the Virgin Artemis" (Casillo 1985, 133). However, because of the later reference to crops, we can conclude that there is indeed a celebration of fecundity in these lines. This fecundity is compatible with the opposite of restraint, the morally ambiguous concept of luxuria which Pound mentions elsewhere in the Cantos, always in the form of a condemnation when it is used in an economic sense, and therefore synonymous with the English "luxury":

And hither came Selvo, doge,

that first mosiac'd [sic] San Marco,

And his wife that would touch food but with forks,

Sed aureis furculis, that is

with small golden prongs

Bringing in, thus, the vice of luxuria; (Pound 1996, XxvI, 122)

However, when luxuria is synonymous with the French luxure (literally "lust" or more precisely a form of liberated sexuality) it is met with much more indulgence by Pound, as in the case of Cunizza in Canto Xxix: 
And she left with a soldier named Bonius

nimium amorata in eum

And went from one place to another

"The light of this star o'ercame me"

Greatly enjoying herself

And running up the most awful bills. (Pound 1996, 142)

24 natural sexual intercourse or that of Eleusis, has been either perverted or "staye[d]" by the "sin against nature" that is usury:

Usura slayeth the child in the womb

It stayeth the young man's courting

It hath brought palsey to bed, lyeth

between the young bride and her bridegroom

CONTRA NATURAM

They have brought whores for Eleusis

Corpses are set to banquet

at behest of usura. (Pound 1996, XLV, 230)

The word "whores" shocks the reader by the virulence of the condemnation it entails and a vulgarity which, to the poet's mind, only reflects that of usury since prostitution is a "commercialization of sexuality" where, one could say, usury, to Pound, is a sexualisation of commerce because it arouses "money-lust" (Pound 1996, XIV, 61) in its devotees.

Pound's censure is also expressed through his use of the Latin word "usura" and the Latin phrase "CONTRA NATURAM". The Latin language seems to carry a certain moral authority which Pound had already played with-in an ironic mode-in Canto $\mathrm{x}$ where we find Pope Pius II's verbose and vituperative condemnation of Sigismundo. In Canto XLV the poet himself becomes invested with that moral authority as he chooses to use Latin without speaking through a persona.

Similarly, he uses archaic English forms and phrases ("slayeth," "stayeth," "at behest of") to evoke a long-standing tradition which usury endangers. This, as well as the use 
of Latin, situates us outside of time, in a uchronia rather than a utopia, illustrating Pound's idea of a "bellum perenne" (Pound, 1996, LXxxvI, 588) between the "man who wants to do a good job" and the usurer (Pound, 1996, LXXXVII, 589).

As we see in the above-quoted passage, this eternal war is, all in all, a war that is waged by usury against fecundity. The infertility we witness in the lines concerned with the wedding rite extends to crops, of course, but also to housebuilding:

with usura, sin against nature,

is thy bread ever more of stale rags

is thy bread dry as paper,

with no mountain wheat, no strong flour (Pound 1996, XLV, 229)

With usura hath no man a house of good stone

each block cut smooth and well fitting (Pound 1996, XLv)

Although there is no reference to genitalia and sexual intercourse is only present in the mention of its absence, we do find images which are reminiscent of a Poundian symbolic representation of intercourse:

or where virgin receiveth message

and halo projects from incision, (Pound 1996, XLV)

In these two lines, as in that which reads "each block cut smooth and well fitting," we find again the image of the phallic line cutting through matter to give shape to thought. Of course, because of the context and the fact that a chisel has previously been mentioned, we know that "incision" here refers to an engraving technique and yet we cannot help seeing in this incision, which by cutting creates light, a "halo," an image reminiscent of what Pound termed "coitu inluminatio" (Pound 1996, XXXVI, 180; LXXIV, 455): an illumination that happens in-that is, through and during-coitus.

\title{
Sacred sexual intercourse, sacred Latinity: the cunnus
}

This coitu inluminatio is visually depicted in the sexual episode in Canto XLVII:

\author{
Hast thou found a nest softer than cunnus \\ Or hast thou found better rest \\ Hast'ou a deeper planting, doth thy death year \\ Bring swifter shoot? \\ Hast thou entered more deeply the mountain?
}

The light has entered the cave. Io! Io!

The light has gone down into the cave,

Splendour on splendour!

By prong have I entered these hills:

That the grass grow from my body,

That I hear the roots speaking together,

The air is new on my leaf,

The forked boughs shake with the wind. (Pound 1996, 238)

As Casillo argues, we find in the above-quoted lines an image of light entering a cave which suggests a sacred event, a procession perhaps, and the name of the goddess Io is chanted as the event takes place (Casillo 1988, 90). The exclamation "Splendour on splendour!"-this noun being commonly found in Dante's Paradiso in which images of divine light are of primordial importance-reinforces the general impression of a sacred event taking place before our eyes. However, as Casillo duly notes, we are also 
presented with images of nature, several of which imitate the movement of sexual penetration (one repeatedly enters the mountain, the hills etc.) while the last ones rather evoke a Whitmanian communion with the grassy earth. The flesh and vegetable elements are joined just as man and woman are joined and it is therefore possible to read, from the perspective of a male speaker, "my leaf" and "[t]he forked boughs" as vegetable metaphors for male and female genitalia respectively.

It is not the only instance in which Pound employs such imagery to refer to genitalia: in Canto XxxIx he uses the simile "her crotch like a young sapling," which explicitly links the human flesh to a vegetable element, and in Canto xxIx he refers to "[o]ur mulberry leaf, woman," where either woman as a whole can be understood to be represented by a mulberry leaf or, if we follow the same line of thought as with the "octopus" and "chaos" that are found in the same Canto, the mulberry leaf could stand for her genitalia, also presenting us with a synechdochical view of woman. This in turn, since the mulberry tree is where the silkworm grows, can be connected with images of silk in the Cantos, most notably that of the "bachi da seta" (the silkworm cocoons) which Italian women, according to Pound, would put in their apron as part of a fertility rite (Pound, 1996, 565; Terrell 469-70). Because of Pound's frequent allusions to rites and because of his insistence on the sacredness of crops, the conflation of human flesh and leaf could be understood as a means to convey to the reader the sacredness of physical unions.

Another, more explicit natural image in the above-quoted passage is the "nest softer than cunnus". In this particular instance, Pound mixes two markers of sacredness: the comparison with nature and Latinity. Indeed, in a chapter of Carta da visita entitled "Gli iconoclasti" which encapsulates Pound's fears concerning the destruction of the Mediterranean civilisation as the war rages on, he celebrates once again "the mystery of fecundity" ("il mistero della fecondità") through elements expected and unexpected: "Il latino è sacro, il grano è sacro." Coitus, despite not being mentioned, is most probably implied in the word "fecondità". It may seem strange that Pound would link the Latin language with a symbol of fertility ("grano") but we should remember that to his mind Latin was not only a language of rite but also one that spawned all the Romance languages which he had so enjoyed studying in his youth. (The result was his collection of essays The Spirit of Romance first published in 1910).

It therefore appears that we find in cunnus not merely an explicit word for the female genitalia: the use of a Latin word may convey the image of a fertility rite. Indeed, Massimo Bacigalupo who calls the two Cantos in which the word "cunnus" appearsCantos XXXIX and XLVII-the "fertility cantos" (Bacigalupo 74) recalls to our minds the presence of the motif of the death-year harvest ("doth thy death year/Bring swifter shoot?") in Canto VI, another Canto that is concerned with sex, and he stresses the idea of death leading to rebirth which is to be found in that motif (Bacigalupo 71, 73). Sexual intercourse, the cultivation of wheat, and the Latin language are connected by their sacredness. Thus, it is not that, as one might suppose, Pound shies away from using an English equivalent that would be more immediately intelligible to his reader: while he has no qualms about using the word "fuck," which is used repeatedly in Canto xxxIx, we never find in all the Cantos any explicit English terms for the female genitalia. This is probably not due to a squeamish reluctance on Pound's part (he would often use such terms in his personal correspondence for instance); rather it might be that, at least in this instance, the Latin word sounded better to Pound in the aural context of the line or 
that he thought it carried more interesting connotations-mainly that of sacredness. It is also possibly an echo of this passage from Canto Xxxix:

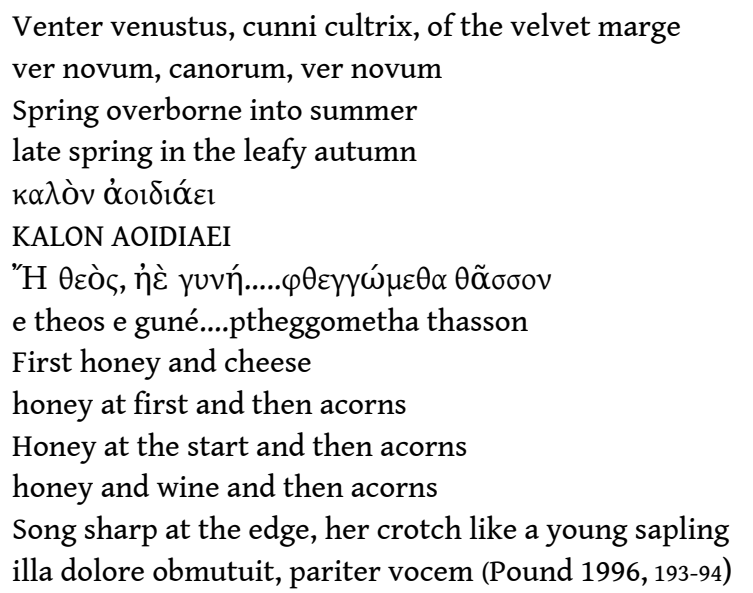

Canto Xxxix has often been commented upon and commentators focus on various aspects. Robert Casillo writes at length of Circe's ambiguous status as both "a dangerous witch and a harlot" who "is identified with a feminine lack of order" (Casillo 1988, 89, 227) and a woman who joins in a sacred union with Odysseus which "anticipates Pound's encounter with Gea Terra (Earth Mother) in Canto 82" (Casillo 1988, 90). William Cookson emphasises the spiritual dimension of the Canto and links it with the coitu inluminatio of Canto XXXVI (Cookson 55). Leon Surette underlines the explicitness of the beginning of the Canto, speaking of "a kind of Hugh Hefner paradise of sensual fatigue" (Surette 84), but quickly moves on to drawing a parallel between Dante's visio beatifica and Pound's version of Odysseus' descent (86); he does not mention the Latin. Both A. David Moody and Peter Davidson remark on the heavy rhythm which translates the drugged atmosphere of the beginning of the poem (Moody 175; Davidson 22). Of all these commentators, only Davidson writes about the Latin phrase "[v]enter venustus, cunni cultrix":

The preceding line, which might be translated, 'belly beautiful, cultivator of her genitals', suggests a skilled, elaborated attitude to the pleasure of love, as opposed to the spontaneous coupling celebrated in the Pervigilium. (Davidson 22)

His translation is technically correct, despite the fact that it does not explicitly show that it is Circe who is the cultivator (cultrix being the feminine of cultor) and does not render the variety of the meanings of cultrix-although, to be fair, that is impossible to do in a single-word translation. The Latin word cultrix denotes a woman who performs the act of colere. The verb colere itself can mean "to cultivate," "to heal," "to inhabit," or "to worship, to honour". ${ }^{4}$ So the cunni cultrix can be merely one who "cultivates" her vulva and learns to know it-or in blunter terms one who is well versed in selfpleasuring-which would give her "a skilled, elaborated attitude to the pleasure of love" or she could be a worshipper, a high priestess of the cunnus. We find again in that very subtle pun-for Pound, a good Latinist from an early age (Stock 12), was most probably aware of the multiple meanings of the word cultrix-an allusion to the sacred dimension of coitus. Because of Pound's ambiguous attitude towards the female genitalia, it is impossible to know with certainty whether the meaning of "worshipper of the vulva" should be taken to be pejorative or not, but this possible translation of the word cultrix, together with the name of the goddess of love, Venus, which we hear in the adjective "venustus" (beautiful), hints at the sacredness of the sexual act. The 
alliteration, in [v] and in [k], adds an aural dimension which supports this sacred dimension as the Latin line can be read in a singing voice, like a ritual chant.

Casillo reflects that the "velvet marge" which completes the line can be understood as the "undefined border of the Pontine Marshes" (a swamp that Mussolini drained, a fact which is later recounted in Canto XLI). The critic also notes that through that image Pound "evokes [Circe's] fundamental undecidability" (Casillo 1988, 228). Although his analysis ties in rather well with the faint trace of disgust towards the female genitalia that we find in other images used by Pound, such as the "octopus," it is also possibleand perhaps more probable-that here "velvet" echoes "venter," and the "ventro" of Canto xxIx. Additionally, this opulent fabric may recall the snugness of a nest, to which the cunnus is later compared in Canto XLVII.

However, this more positive interpretation of Pound's text should not distract us from the violence lurking behind the appearance of softness. As previously mentioned, violence is almost consistently erased by Pound, even when he alludes to rapes found in classical texts. Because he so staunchly refuses to see it, violence can only remain, partly concealed but never well enough, in the form of ambiguity. This ambiguity is especially present in the representations of female genitalia, which range from the strangely disgusting warmth of familial affection to the bucolic image of the soft nest. Circe, an adversary with whom Ulysses must consort in a fertility rite (Bacigalupo 70, 73), epitomises this ambiguity towards women's willing participation in sexual intercourse (Greer 278). Pound's tendency to resort to mythical images, the use of Latin and the references to the agricultural world, may compel us to think that the choice of the word cunnus, this sacred vessel, is detached from history-and indeed that is probably Pound's intention-but Bacigalupo warns us against such a misconception and links Pound's celebration of sex as a fertility rite with Mussolini's own fertility policies, with regard to both women and agriculture (Bacigalupo 71). He even goes as far as associating Pound's Circe with Fascism (Bacigalupo 53). Pound's decision to use a Latin word may be tied to a memory of reading the ribald classics (Gery 189), but his regard for Latin is also intricately linked to his appreciation for certain aspects of Italian culture that Fascism favoured, as the above-mentioned extract from Carta da visita shows. In the Fascist discourse as in the patriarchal, violence is hidden from sight because it is in the interest of the oppressor that his oppression is not recognised as such by his victim. It is a rhetoric with which Pound's poetics aligns completely.

\section{Conclusion}

Following Casillo's and Bacigalupo's intuitions and relying on Braun and Wilkinson's typology of negative representations of the vagina (and by extension of the entire female genitalia) $)^{5}$ in Western societies, we can determine that Pound's representations fit certain, but not all, of the stereotypes that the two researchers have identified. The female genitalia are seen as-at least symbolically-inferior to the penis since the vulva, unlike the phallus, has no creative role and, as Dennis points out, it is seen as "something of a biological mess at times"; they remain, however, complementary with the male genitalia and are never deemed "sexually inadequate" by the poet (Dennis 2010, 406-407). The vagina is never seen as dangerous, even in the case of the morally ambiguous Circe, or as an absence in the Freudian sense (Braun and Wilkinson, 19)-although one could argue that there is a lack in that it needs the phallic energy of 
man to give it purpose. It is not "vulnerable and abused" either-perhaps first and foremost because from the perspective of this rather traditional heterosexual male, sexual intercourse could never be perceived as rape-but we should also note that the consistent absence of any indication of sexual violence or male pleasure found in domination and violent intercourse does not preclude the hidden presence of violence, especially on a political level, be it totalitarian politics or sexual politics (Millett 23-24).

Pound's representations of the female genitalia tend to oscillate between the slightly disgusting (they are messy, chaotic, sometimes associated with people-Jews or rather what they symbolised for him as an abstraction-and places-London-which Pound found repulsive) and the nearly-mystic, the vulva being a passive receptacle for the energetic penis, a fertile soil (soil being sometimes seen as dirty too) for the sowing and ploughing (a word that is often found-perhaps not merely coincidentally-in the Cantos). With their characteristic oscillation between the repulsive and the sacred and with their conflation of natural images and Latinity these representations of the female genitalia are to be related to Pound's preoccupation with economics and political and social life. The morally vested Latin language serves to underline both the sacred (the cunnus that is to be penetrated in the rite of coitus, the coitu inluminatio that happens in that process) and the sinful (usura, contra naturam). The ambiguous luxuria, like the ambiguous female genitalia, should be thought of in relation to Pound's often implicit distinction between desire for an abstract object (in the form of money-lust for example) and desire for a concrete object (a house of good stone, crops, intercourse): the concrete is linked to the sacred whereas abstraction leads, in Pound's mind, to perdition.

\section{BIBLIOGRAPHY}

Bacigalupo, Massimo. The Forméd Trace: The Later Poetry of Ezra Pound. New York: Columbia University Press, 1980.

Beauvoir, Simone de. Le Deuxième sexe, tome I : Les faits et les mythes. 1949. Paris: Gallimard, 1986.

Braun, Virginia, and Sue Wilkinson. "Sociocultural representations of the vagina". Journal of Reproductive and Infant Psychology 19 (February 2001): 17-32.

Casillo, Robert. The Genealogy of Demons: Anti-Semitism, Fascism, and the Myths of Ezra Pound. Evanston: Northwestern University Press, 1988.

---. "Troubadour Love and Usury in Ezra Pound's Writings". Texas Studies in Literature and Language 27:2 (1985): 125- 153. Last accessed 3 December 2019. <www.jstor.org/stable/40754771>.

Cookson, William. A Guide to the Cantos of Ezra Pound. London: Anvil Press Poetry, 2001.

Davidson, Peter. Ezra Pound and Roman Poetry: A Preliminary Survey. Amsterdam: Rodopi, 1995.

Dennis, Helen. "Pound, women and gender". In The Cambridge Companion to Ezra Pound. Ed. Ira B. Nadel. Cambridge: Cambridge University Press, 1999. 264-283. 
---. "Gender and sexuality". In Ezra Pound in Context. Ed. Ira B. Nadel. Cambridge: Cambridge University Press, 2010. 402-411.

Edwards, John Hamilton et al. Annotated Index to The Cantos of Ezra Pound: Cantos I-LXXXIV. Berkeley: University of California Press, 1957.

Gaffiot, Félix. Dictionnaire illustré latin-français. Paris : Hachette, 1934.

Gery, John. “'The Thought of What America': Ezra Pound's Strange Optimism," Belgrade English Language and Literature Studies II (2010): 187-206. Last accessed 13 December 2019.

<https://www.academia.edu/5600344/

The_Thought_of_What_America_Ezra_Pound_s_Strange_Optimism>.

Gourmont, Remy de. The Natural Philosophy of Love. Trans. E. Pound. New York: Boni and Liveright, 1922. Last accessed 25 July 2019.

<http://archive.org/details/naturalphilosophoogouriala>.

Greer, Germaine. The Female Eunuch. London : Flamingo, 1993. Last accessed 22 April 2020.

<http://archive.org/details/femaleeunuc000gree>.

H.D. (Hilda Doolittle). End to Torment : A Memoir of Ezra Pound. New York: New Directions, 1979.

Last accessed 28 April 2020.

<http://archive.org/details/endtotormentmemooohdhi>.

Labuski, Christine. "Vulnerable Vulvas: Female Genital Integrity in Health and Dis-ease". Feminist Studies 39:1 (2013): 248- 276. Last accessed 28 March 2020.

$<$ https://www.jstor.org/stable/23719315>.

Makin, Peter. Pound's Cantos. London and Boston: George Allen and Unwin, 1985.

---. Provence and Pound. Berkeley: University of California Press, 1978.

Millett, Kate. Sexual Politics. Urbana and Chicago: University of Illinois Press, 2000.

Moody, A. David. Ezra Pound: Poet: Volume II: The Epic Years. Oxford: Oxford University Press, 2014.

Nicholls, Peter. “'A Consciousness Disjunct': Sex and the Writer in Ezra Pound's 'Hugh Selwyn Mauberley”'. Journal of American Studies 28:1 (1994): 61-75. Last accessed 19 February 2020. $<$ https://www.jstor.org/stable/27555784>.

Paul, Catherine E. Fascist Directive. Clemson: Clemson University Press, 2018.

Pound, Ezra. ABC of Reading. London: Faber and Faber, 1961.

---. The Cantos. New York: New Directions, 1996.

---. Ezra Pound Speaking: Radio Speeches of World War II. Ed. Leonard Doob. Westport and London: Greenwood Press, 1978.

---. Jefferson And/Or Mussolini. L'Idea statale. Fascism as I Have Seen It. London: Stanley Nott Ltd., 1935. Last accessed 3 May 2017.

<http://archive.org/details/JeffersonAndOrMussoliniPound1935>.

---. Literary Essays. Ed. T. S. Eliot. New York: New Directions, 1968.

---. Selected Prose, 1909-1965. Ed. William Cookson. London: Faber \& Faber, 1973.

---. "Canto XxVII". The Cantos Project. Last accessed 20 August 2019.

<http://thecantosproject.ed.ac.uk/index.php/canto-17-27-overview/canto-xxvii?start=1>.

Rabaté, Jean-Michel. Language, Sexuality, and Ideology in Ezra Pound's Cantos. Albany: State

University of New York Press, 1986. 
Sieburth, Richard. "In Pound We Trust: The Economy of Poetry/The Poetry of Economics". Critical Inquiry 14:1 (1987): 142- 172. Last accessed 12 December 2018.

<https://www.jstor.org/stable/1343576>.

Stock, Noel. The Life of Ezra Pound. 1970. San Francisco: North Point Press, 1982.

Surette, Leon. A Light from Eleusis: A Study of Ezra Pound's Cantos. 1979. Bloomington: Xlibris Corporation, 2000.

Terrell, Carroll F. A Companion to the Cantos of Ezra Pound. 1984. Berkeley: University of California Press, 1993.

Ten Eyck, David. “Romance Languages”. In Ezra Pound in Context. Ed. Ira B. Nadel. Cambridge: Cambridge University Press, 2010. 43-53.

\section{NOTES}

1. This phrase is generally translated as "wine, women and song" and is also the title of a waltz by Johann Strauss II.

2. Examples of such jokes include the English phrase "the old ball and chain" to designate one's wife and the French phrase "se faire passer la corde au cou" (to get tied down, meaning to get married).

3. These are made available at < http://thecantosproject.ed.ac.uk/index.php/canto-17-27overview/canto-xxvii?start=1>

4. See Gaffiot's Dictionnaire illustré latin-français $(1934,344)$ for the definition of "colere" and its French translations. The translation into English of those words found in the definition is mine.

5. The importance of distinguishing between the vulva in its entirety and the vaginal opening has been underlined by Christine Labuski, because referring to the vulva may help avoid the assignation to the role of a passive receptacle, a common problem in heterosexual representations of female genitalia (Labuski 227).

\section{ABSTRACTS}

This paper focuses on the ways in which Ezra Pound chose to represent the female genitalia in his Cantos. The discussion of these representations is based on the work of Poundian scholars such as Peter Makin, Robert Casillo, and Jean-Michel Rabaté who have dealt with the place of sexuality in Pound's poetry, but it also aims to offer new insights, relying both on works of feminist scholarship and on an analysis of Pound's use of Latin in the context of sexuality.

Cet article s'intéresse aux diverses manières dont Ezra Pound représente les parties génitales féminines dans ses Cantos. L'étude de ces représentations s'appuie sur le travail de chercheurs poundiens tels que Peter Makin, Robert Casillo et Jean-Michel Rabaté qui ont traité par le passé de la place de la sexualité dans la poésie de Pound, mais elle cherche aussi à offrir de nouvelles perspectives grâce aux travaux de penseuses et chercheuses féministes et à travers une analyse de l'emploi du latin par Pound dans le contexte de la sexualité. 
INDEX

Keywords: modernism, obscene, Ezra Pound, The Cantos, genitalia, representations of woman, femininity, poetry, American poetry

Mots-clés: modernisme, obscène, Ezra Pound, Les Cantos, parties génitales, représentations de la femme, féminité, poésie, poésie américaine

\section{AUTHORS}

\section{EMILIE GEORGES}

$\mathrm{PhD}$ student/doctorante contractuelle

Université Paris Nanterre

emilie.georges@parisnanterre.fr 